\title{
Pengembangan Industri Jamur Tiram dan Buah Naga dalam Menjaga Pluralitas dan Keberagaman Desa Kesilir Kecamatan Siliragung Kabupaten Banyuwangi
}

\author{
Mahmudah', Nawal Ika Susanti² \\ 1Fakultas Dakwah dan Komunikasi, ${ }^{2}$ Fakultas Ekonomi dan Bisnis Islam, \\ IAI Darussalam Blokagung Banyuwangi \\ Email: ${ }^{1}$ mahmudah.iaida@gmail.com, ${ }^{2}$ nawalika@iaida.ac.id
}

\begin{abstract}
Kesilir Village is a village famous for its Dragon Fruit paradise, located in Siliragung District, Banyuwangi Regency. This village has 3 hamlets namely Sumbersuko, Sumberbening and Silirsari hamlets. General conditions of assistance 1) The number of Oyster Mushroom farmers who are not developing their business; 2) Most of the Oyster Mushroom Farmers did not continue their business; 3) The reduced stock of Oyster Mushrooms in the market; 4) Lack of creativity of Oyster Mushroom farmers to innovate their products; 5) Less innovation in Dragon Fruit Processing; 6) Many Dragon Fruit farmers suffer losses; 7) Most of the youth only rely on laborers. After the utilization of oyster mushrooms and dragon fruit lunkhead followed by the Sumberbening youths united, the community felt very helpful in solving these annual problems such as if the price of Dragon fruit decreased and there was less innovation in the processing of Oyster Mushrooms. This program received a positive response from the youth of Sumberbening because of the increasing economic problems of the community so that this activity could be used as a home industry that unites differences and can increase the income of the surrounding community.
\end{abstract}

Keywords: Empowerment, Dragon Fruit, Oyster Mushrooms

\section{Pendahuluan}

Potensi sektor basis di Kabupaten Banyuwangi hasil analisis Tipologi klassen menunjukkan sektor yang dikategorikan sebagai sektor maju dan tumbuh pesat (sektor prima) adalah Sektor Pertanian dan sektor yang terbelakang adalah sektor Industri Pengolahan, Perdagangan, Hotel dan Restoran, Pengangkutan dan Komunikasi, dan Jasa-jasa. ${ }^{1}$ Sektor pertanian

${ }^{1}$ JAUHARIYAH, Nur Anim. Kebijakan Pengentasan Kemiskinan Melalui Kajian Potensi Sektor Basis Di Kabupaten Banyuwangi. Jurnal Darussalam: Jurnal Pendidikan, Komunikasi dan Pemikiran Hukum Islam, [S.l.], v. 7, n. 1, p. 112-126, sep. 2015. ISSN 2549-4171. 
merupakan sektor yang masih memberikan kontribusi bagi pertumbuhan ekonomi di Banyuwangi. ${ }^{2}$

Desa Kesilir merupakan desa yang terkenal akan surganya Buah Naga yang terletak di Kecamatan Siliragung Kabupaten Banyuwangi. Desa ini memiliki 3 dusun yaitu Dusun Sumbersuko, Sumberbening dan Silirsari di bawah pimpinan bapak Supriyanto selaku kepala Desa Kesilir yang baru menjabat selama 1 tahun. Luas tanah Desa Kesilir mencapai kurang lebih 492, 250 Ha yang sebagian besar berprofesi sebagai petani Buah Naga. ${ }^{3}$

Keadaan demografis Desa Kesilir yang dimulai dari jumlah dusunnya terdapat tiga dusun yaitu dusun Sumbersuko : $6 \mathrm{RW}$ dan $30 \mathrm{RT}$, dusun Sumberbening : 6 RW dan 26 RT, Dusun Silirsari 5 RW dan 17 RT. Sedangkan dilihat dari jumlah penduduknya yang terdiri dari tiga dusun, yang pertama Dusun Sumbersuko untuk jumlah penduduk laki-laki dan perempuan dengan total 3099,dengan jumlah KK 1258, sedangkan Dusun Sumberbening untuk jumlah penduduk laki-laki dan perempuan dengan total 2437, dengan jumlah KK 1002, dan Dusun Silirsari jumlah penduduk laki-laki dan perempuan 1402, dengan jumlah KK 590. ${ }^{4}$

Kondisi dampingan secara umum 1) Banyaknya petani Jamur Tiram yang kurang mengembangkan usahanya; 2) Sebagian besar Petani Jamur Tiram tidak melanjutkan usahanya; 3) Berkurangnya stok Jamur Tiram di pasaran; 4) Kurangnya kreatifitas petani Jamur Tiram untuk menginovasi produknya; 5) Kurang inovasi dalam Pengolahan Buah Naga; 6) Banyak petani Buah Naga yang mengalami kerugian; 7) Sebagian besar pemuda hanya mengandalkan buruh kerja.

Available at: <http://ejournal.iaida.ac.id/index.php/darussalam/article/view/54>. Date accessed: 15 dec. 2020.

2Jauhariyah, Nur Anim dkk. Disparitas Antar Kecamatan Dan Strategi Pembangunan Ekonomi di Kabupaten Banyuwangi. diakses 16 Agustus 2019. http://jurnal.unissula.ac.id/index.php/cbam/article/view/170/0

${ }^{3}$ Profil Desa Kesilir, 2019

4Profil Desa Kesilir, 2019 
PAR yang melibatkan partisipasi masyarakat dengan harapan dapat memberdayakan Masyarakat dalam hal-hal 1) Masyarakat dapat mengembangkan usahanya; 2) Masyarakat dapat melanjutkan usahanya; 3) Bertambahnya stok Jamur Tiram di pasar tidak hanya dari salah satu pihak; 4) Bertambahnya kreatifitas Masyarakat untuk menciptakan inovasi produk dari hasil produksi Jamur Tiram; dan 5) Mendorong para pemuda untuk menciptakan lapangan kerja.

\section{Metode}

Pemberdayaan ini menggunakan pendekatan Participatory Action Research (PAR). ${ }^{5}$ Dengan melakukan penggalian kembali terhadap permasalahan yang terjadi. Pada uraian ini akan dipaparkan beberapa aksi yang dilakukan oleh tim pendamping sebagai langkah awal untuk menggali dan mencarikan solusi terhadap permasalahan yang ada di Desa Kesilir Kecamatan Siliragung Kabupaten Banyuwangi tersebut.

Desa Kesilir mempunyai aset yang sangat banyak, akan tetapi dari kebanyakan penduduk belum tahu cara bagaimana menggunakan aset tersebut. Terutama aset dari pembudidayaan Jamur Tiram, karena di desa Kesilir terdapat penduduk yang mempunyai usaha budidaya Jamur Tiram tetapi belum bisa untuk memanfaatkan menjadi produk yang lebih menguntungkan. Permasalahan pertama yang ada di desa Kesilir yaitu belum adanya pemanfaatan Jamur Tiram dan buah Naga di karenakan kurangnya pemikiran yang kreatif, sehingga Jamur Tiram dan buah Naga seolah - olah hanya di perjual belikan mentahan saja. Permasalahan selanjutnya yaitu belum pernah ada pelatihan pembuatan bibit Jamur Tiram. Dan harga buah Naga yang tidak bisa stabil.

5 INAYAH, Nurul et al. Pemberdayaan Masyarakat Dalam Usaha Peningkatan Pendapatan Keluarga Sejahtera (UPKKS). LOYALITAS, Jurnal Pengabdian Kepada Masyarakat, [S.l.], v. 2, n. 1, p. 112-123, may 2019. ISSN 2621-4687. Available at: <http://ejournal.iaida.ac.id/index.php/loyal/article/view/409>. Date accessed: 15 dec. 2020.

Pengembangan Industri Jamur Tiram dan Buah Naga dalam Menjaga Pluralitas dan 
Pola pikir masyarakat desa Kesilir masih sangatlah standar, hanya dengan menggunakan pikiran pikiran yang instan saja sehingga dapat mengakibatkan kurangnya pengetahuan dalam pembibitan. Dan di masyarakat desa Kesilir belum pernah di adakan pelatihan pemanfaatan Jamur Tiram dan dodol buah Naga. Sehingga menimbulkan dampak kurang kesadaran akan omset yang bernilai tinggi. Sedikitnya masyarakat yang mempunyai indistri pembibitan Jamur Tiram juga akan menyebabkan lemahnya keahlian petani dalam pembibitan Jamur Tiram. Di desa Kesilir banyak petani Jamur Tiram, akan tetapi dalam segi pembibitannya masih belum bisa maksimal, jadi bisa mengakibatkan kurangnya pasokan Jamur Tiram di pasar.

Selain itu, permasalahannya adalah harga buah Naga yang tidak bisa stabil membuat buah Naga sering dibuang-buang. Maka kelompok membuat alternatif membuat dodol buah Naga untuk menghindari kerugian yang banyak.

\section{Hasil dan Diskusi}

Strategi Pelaksanaan Program

\section{Jenis Program Kegiatan}

Hasil observasi dan wawancara yang dilakukan bersama perangkat desa, tokoh masyarakat, masyarakat sekelompokr, serta adanya musyawarah dan kerjasama dengan stakeholder maka dilaksanakan program pelatihan mengembangkan potensi industri Jamur Tiram dan Buah Naga sebagai terobosan perekonomian di Desa Kesilir.

Jamur Tiram adalah jamur pangan dari kelompok basidiomycota dan termasuk kelas homobasidiomicetes dengan ciri-ciri umum tubuh buah bewarna putih hingga krem dan tudungnya berbentuk setengah lingkaran mirip cangkang tiram dengan bagian tengah agak cekung. Jamur Tiram terbuat dari sisa serbuk kayu yang dicampur dengan kalsium karbonat dan 
diseterilkan dalam drum setelah itu didinginkan dalam waktu 1 hari diruangan yang tertutup, yang nantinya timbal balik akan diperoleh oleh petani Jamur.

Buah Naga adalah buah dari beberapa jenis kaktus dari marga Hylocereus yang berasal dari negara Meksiko dan Amerika. Namun, sekarang juga dibudidayakan di Negara-negara asia. Begitu juga di negara Indonesia. Buah ini memiliki dua junis yakni buahnya berwarna merah dan putih namun kulitnya tetap sama.

2. Pengelolaan Jamur Tiram

Petani Jamur Tiram adalah seseorang yang bertanggung jawab mulai dari membuat benih Jamur Tiram, merawat sampai memanen jamur. sementara jamur yang sudah dipanen nantinya dijual kepasar-pasar ataupun ke agen produksi dari Jamur Tiram.

Petani Jamur Tiram dalam pengelolaanya ini menghendel keseluruhan tentang pembudidayaan Jamur tersebut dengan tenaga sendiri mulai dari membuat benih, menyeterilkan, menyirami dan memanennya. Setiap jamur tiram yang memiliki nilai jual bisa untuk dipasarkan atau diproduksi dengan kriteria sesuai dengan kelayaan dan kualitas Jamur Tiram.

Dari pemaparan Jamur Tiram diatas maka dapat disimpulkan bahwa pembudidayaan Jamur Tiram sangatlah mudah dan banyak diminati oleh petani jamur yakni meliputi pencampuran bahan, pencetakan, penanaman benih, pensterilan, dan menjaga kelembapan. Maka dari itu kelompok kelompok 12 memilih bidang garapan yaitu memberikan pelatihan kewirausahaan budidaya jamur tiram guna untuk meningkatkan perekonomian masyarakat Desa Kesilir. 


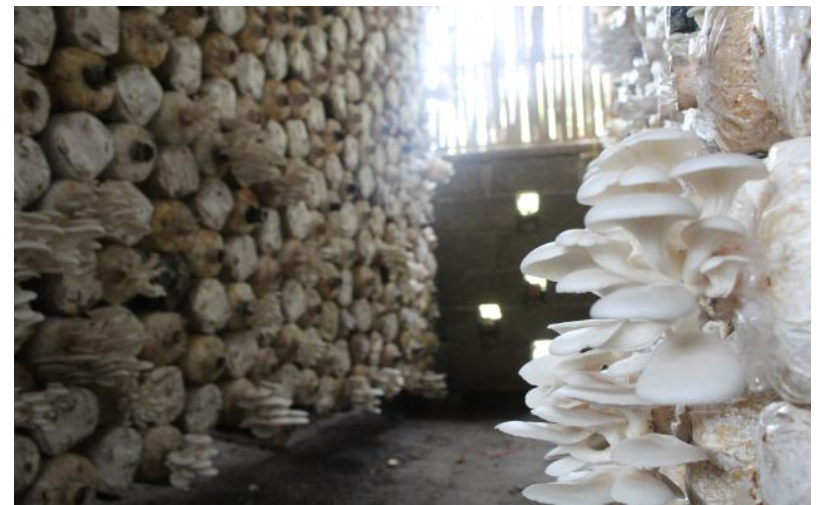

\section{Gambar 1. Budidaya Jamur Tiram di Desa Kesilir (Sumber: Dokumentasi, 2019)}

Petani buah Naga adalah orang yang bertanggung jawab atas keseluruhan pertanian buah Naga . Mulai dari penanaman batang buah naga, mengawinkan, penggibroan, dan pemasaran. Dalam pengelolaan ini petani yang mengatur secara keseluruhan terkait Buah Naga. Mulai dari perawatan dan pemanfaatannya di pasaran. Dengan begitu, pertanian buah Naga sangatlah baik untuk dijadikan asset pertanian dan pemanfaatan. Mengingat jika buah Naga banyak dan harga tidak stabil maka dapat di inovasi untuk pelbagai produk.

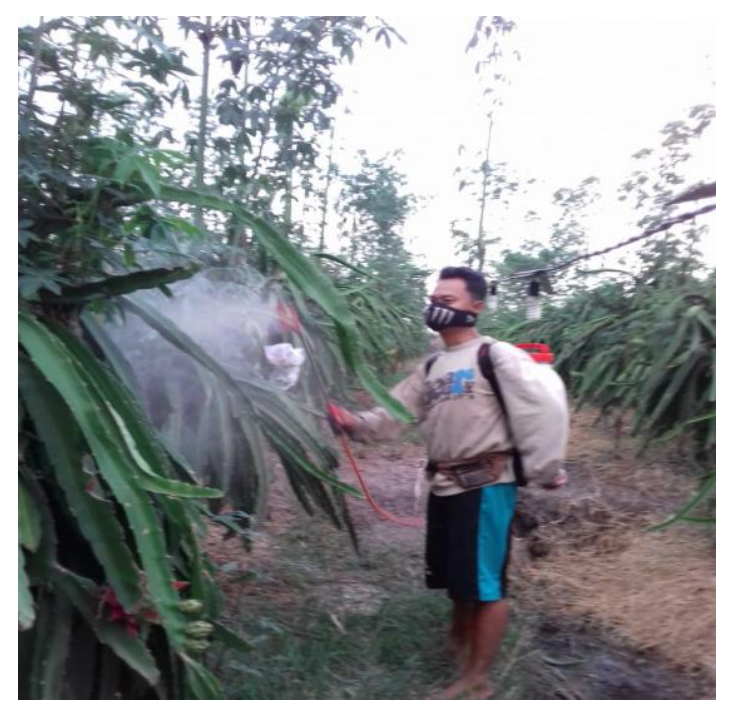

Gambar 2. Petani Buah Naga (Sumber: Dokumentasi, 2019)

Pengembangan Industri Jamur Tiram dan Buah Naga dalam Menjaga Pluralitas dan 
Berdasarkan hasil wawancara dengan sekertaris desa dan survey yang telah dilakukan oleh kelompok 12 akhirnya memutuskan untuk bekerja sama dengan pemuda Dusun Sumberbening. Dikarenakan diantara ketiga komunitas tersebut komunitas Dusun Sumberbening merupakan komunitas paling aktif dan kompak untuk melakukan suatu kegiatan. Selain itu, komunitas tersebut mempunyai nilai partisipasinya sangat tinggi. Anggota komunitas tersebut berjumlah 39 orang. Namun, tidak semuanya ikut terlibat dalam suatu kegiatan. Dikarenakan mereka mempunyai latar belakang pekerjaan yang berbeda-beda. Berikut merupakan daftar nama komunitas Dusun Sumberbening.

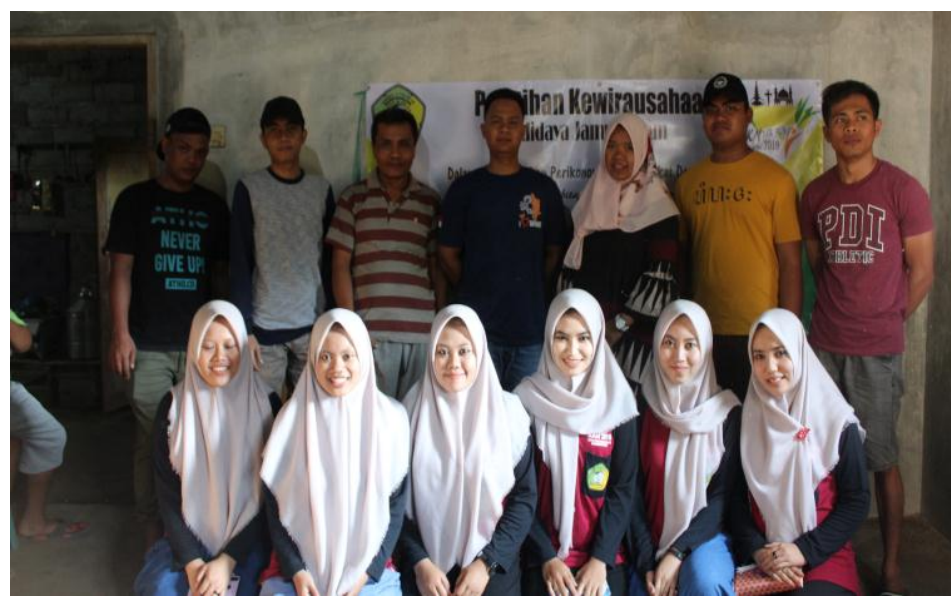

\section{Gambar 3. Foto Setelah Pelatihan Pembibitan Hingga Pemanfaatan Jamur Tiram Bersama Pemuda (Sumber: Dokumentasi, 2019)}

\section{Strategi Pelaksanaan Program}

Dalam suatu kegiatan tentunya tidak terlepas dengan strategi yang akan dilakukan. Berikut adalah strategi-strategi yang dilakukan untuk mencapai kegiatan yang diagendakan. Adapun kegiatannya meliputi:

a. Kegiatan pelatihan pembibitan dan pengolahan Jamur Tiram Langkah-langkah yang dilakukan adalah:

1) Berdiskusi dengan sekrertaris desa mengenai potensi aset yang ada di Desa Kesilir 
2) Survey di lapangan potensi Desa Kesilir

3) Diskusi dengan kelompok untuk merencanakann kegiatan PAR

4) Koordinasi dengan pembimbing lapangan mengenai rencana kegiatan program PAR

5) Koordinasi dengan perangkat Desa Kesilir mengenai rencana kegiatan program PAR

6) Koordinasi dengan petani Jamur Tiram mengenai proses pembibitan Jamur Tiram

7) Kelompok melakukan ekperimen pembuatan abon Jamur Tiram yang pertama

8) Koordinasi dengan ibu kepala desa mengenai objek yang direncanakan

9) Kordinasi dengan pemuda Dusun Sumberbening tentang rencana kegiatan program PAR

10) Melakukan proses pelatihan proses pembibitan Jamur Tiram bersama pemuda Dusun Sumberbening

11) Kelompok melakukan ekperimen pembuatan abon Jamur Tiram kedua

12) Melakukan proses mensterilkan bibit Jamur Tiram

13) Melakukan proses menanaman benih Jamur Tiram

14) Melakukan pengolalahan Abon Jamur Tiram

15) Melakukan desain bersama pemuda Dusun Sumberbening untuk pelebelan.

16) Diskusi mengenai pengemasan hingga pemasaran produk

17) Surver di toko sekitar Desa Kesilir mengenai patokan harga

18) Survey ke toko-toko sekitar Dusun Sumberbening yang siap dititipkan produk hasil pemuda tersebut

19) Mendampingi pemuda untuk memasarkan produk yang ada. 
20) Pengulangan dalam pembibitan dan pengolahan Jamur Tiram dan Buah Naga

21) Membantu dalam pembuatan struktur organisasi pemuda Dusun Sumberbening bersatu

b. Kegiatan pemanfatan Buah Naga

1) Musyawarah dengan komunitas pemuda Dusun Sumberbening bersatu mengenai pemanfaatan Buah Naga

2) Musyawarah dengan perangkat desa mengenai pemanfatan Buah Naga

3) Diskusi dengan pemuda Dusun Sumberbening mengenai bahanbahan yang harus dipersiapkan

4) Melakukan pelatihan pengolalahan Dodol Buah Naga

5) Melakukan desain bersama pemuda Dusun Sumberbening untuk pelebelan.

6) Diskusi mengenai pengemasan hingga pemasaran produk

7) Surver di toko sekitar Desa Kesilir mengenai patokan harga

8) Survey ke toko-toko lingkungan Sumberbening yang siap dititipkan produk hasil pemuda dengan kelompok 12

9) Mendampingi pemuda untuk memasarkan produk yang ada.

10) Pengulangan dalam pembibitan dan pengolahan Buah Naga

11) Membantu dalam pembuatan struktur organisasi pemuda Dusun Sumberbening bersatu.

Kelompok mulai mensurvey lokasi yang akan dijadikan program kegiatan yang akan dijadikan program PAR pada hari Minggu tanggal 15 September 2019. Hasil wawancara dengan Bapak Sujoko terkait budidaya Jamur Tiram dari pembibitan hingga proses memanen jamur. Beliau menjelaskan bahwa sebelum melakukan pembibitan di butuhkan baglog dengan bahan-bahan sebagai berikut: 

a. $20 \%$ Katul
b. $50 \%$ Serbuk kayu
c. $25 \%$ Kalsium karbonat
d. 5\% Air

Setelah bahan-bahan itu lengkap maka proses pembuatan baglog sebagai wadah pembenihan Jamur Tiram dapat dilaksanakan. Setelah baglog selesai maka langkah selanjutnya dilakukan pensterilan baglog. Hal ini dilakukan agar jamurnya dapat berkembang dengan maksimal. Proses pensterilan dibutuhkan waktu 1 hari dan di dinginkan 1 hari. Setelah baglog steril dan sudah dingin maka selanjutnya adaah proses pembbitan, dimana daam proses ini harus di ruang kedap udara.

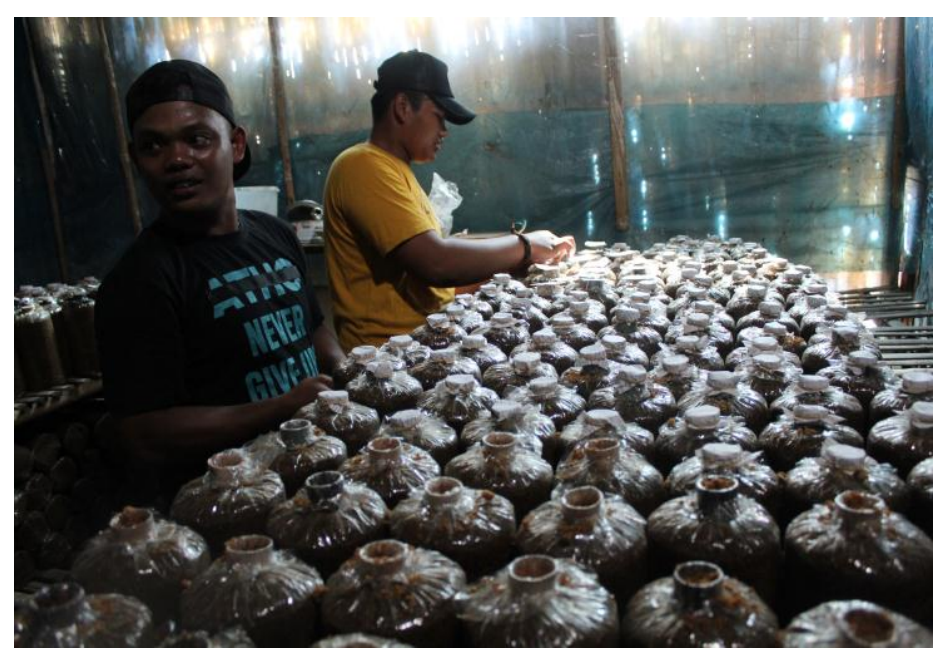

\section{Gambar 4. Proses Penanaman Benih Jamur Tiram (Sumber: Dokumentasi, 2019)}

Koordinasi persiapan pengolahan Buah Naga menjadi dodol Buah Naga

Pada hari Sabtu tanggal 21 September 2019 kelompok merencanakan bersama pemuda Dusun Sumberbening untuk melakukan diskusi terkait bahan-bahan apa saja yang diperklukan untuk pengolahan dodol Buah Naga. Yakni bahan-bahan tersebut adalah: 
a) Buah Naga $3 \mathrm{~kg}$

b) Santan kelapa $300 \mathrm{ml}$

c) Tepung beras $1 / 4 \mathrm{~kg}$

d) Tepung ketan $1 / 4 \mathrm{~kg}$

e) Gula putih $1 \mathrm{~kg}$.

Dalam pembuatan dodol Buah Naga kelompok datang kerumah salah satu pemuda Dusun Sumberbening. Kelompok mengarahkan tentang bagaimana cara pengolahan yang benar hingga pengemasan dan pemasaran. Hal tersebut dilaksanakan pada hari Selasa, 2409 2019. Dengan langkahlangkah sebagi berikut:

a) Kupas Buah Naga yang telah disiapkan sebanyak $3 \mathrm{~kg}$

b) Haluskan dengan tangan hingga berubah menjadi cairan.

c) Setelah itu, kelapa parut dibagi menjadi dua. Yang pertama di sangray dan yang kedua di peras untuk mengambil cairan santanya.

d) Tepung ketan dan tepung beras dicampurkan dengan santan kelapa

e) Pada wadah yang lain cairan buah naga tersebut di panaskan hingga kanduangan air berkurang.

f) Setelah itu dicampur dengan adonan campuran santan, tepung beras, dan tepung ketan.

g) Setelah itu proses pemasakan memakan waktu selama 5 jam sambil diaduk-aduk

h) Setelah 5 jam adonan menjadi kalis dan kenyal di tuangkan dalam wadah lalu dibiarkan agar dingin.

Setelah itu, dipotong-potong dengan panjang $4 \mathrm{~cm}$ dan dikemas menggunakan plastik dan selanjutnya dikemas dalam mika. Dan tiap mika berisi 15 dodol Buah Naga 

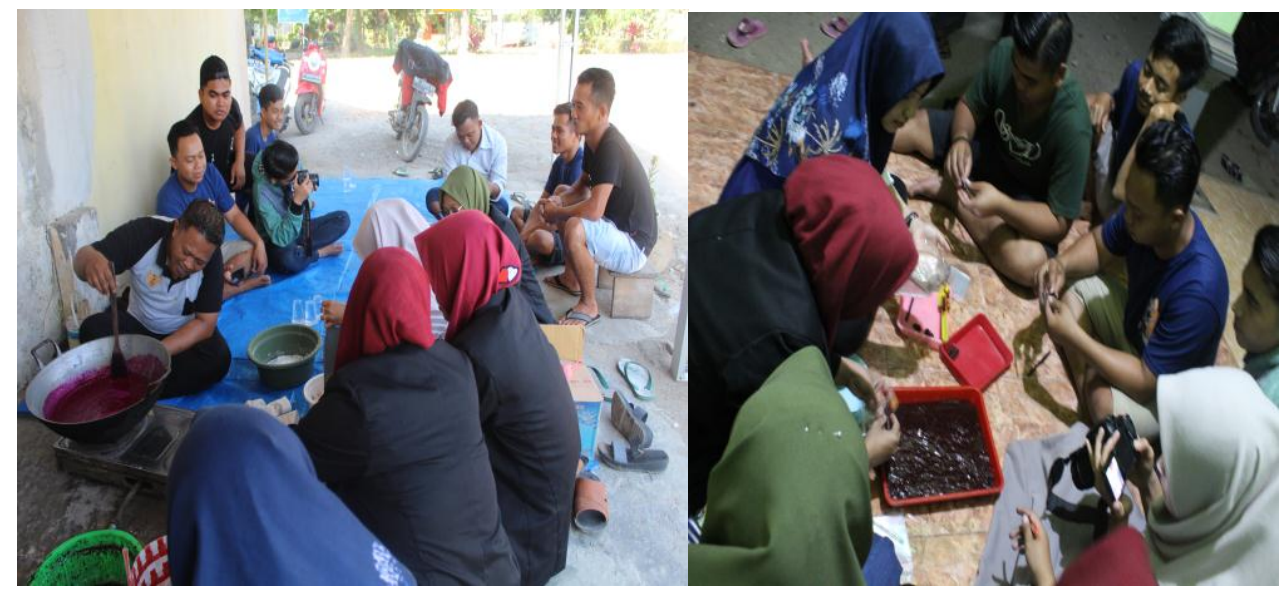

Gambar 5. Proses Pembuatan dan Pengepakan

Dalam Pemanfatan Buah Naga menjadi dodol Buah Naga (Sumber: Dokumentasi, 2019)

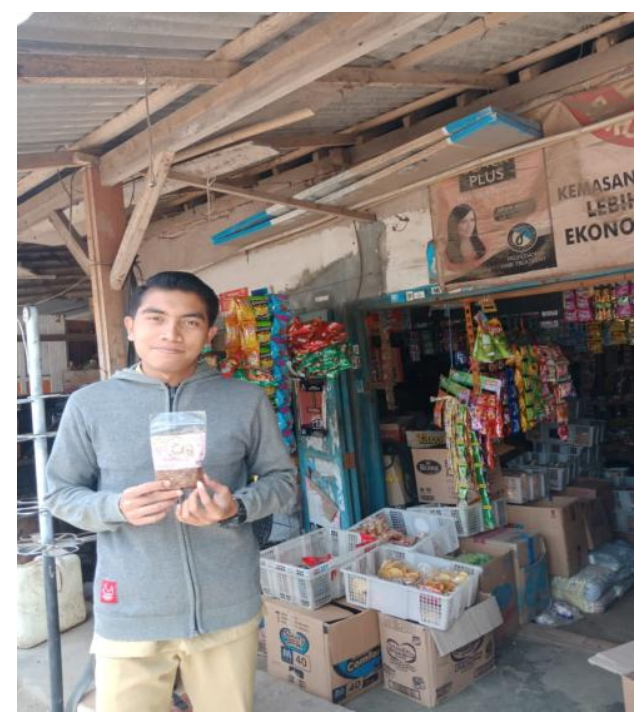

\section{Gambar 6. Pemasarkan Produk Di Toko Sekitar} (Sumber: Dokumentasi, 2019)

Harga patokan yang digunakan dibanyak kalangan pemasaran. Sehingga kami bersepakat untuk patokan harga dengan margin sebagai berikut:

a. Harga jual Abon Jamur Tiram

Harga produk: 
- Jamur Tiram $6 \mathrm{~kg}$

- Bawang Putih $1 \frac{1}{2} \mathrm{~kg}$

- Kemiri 1 bungkus

- Tumbar 1 bungkus

- Jinten 1 bungkus

- Gula, Garam, Masako

- Daun Jeruk

- Minyak goreng $1 \mathrm{~kg}$

- Tisu

- Kemasan\&lebel

- Selep Jamur Tiram Jumlah Margin

$50 \div 120 \times 127.000=63.500$

$($ Biaya + Margin $) /$ Jumlah produk $=(127+63.500) / 19=10.000$
: Rp 60.000

: Rp 6.000

: Rp 4.000

: Rp 1.000

: Rp 4.000

: Rp 5.000

: Rp 1.000

: Rp 15.000

: Rp 2.000

: Rp 19.000

: Rp 10.000

Rp. 127.000

b. Harga jual dodol Buah Naga :

Harga produk

- Buah Naga : Rp 40.000

- Tepung ketan \& beras

: Rp 10.000

- Gula pasir : Rp 10.000

- Plastik kemasan : Rp 3.000

- Kemasan mika \& label : Rp 3.000 Jumlah

Rp 66.000

Margin

$50 \div 100 \times 66.000=33.000$

$($ Biaya + Margin $) /$ Jumlah produk $=(66+33) / 10=9.900=10.000$ 


\section{Simpulan}

Setelah adanya pemanfaatan jamur tiram dan dodol buah Naga yang diikuti pemuda Sumberbening bersatu, sehingga masyarakatpun merasa sangat terbantu dalam menyelesaikan masalah tahunan seperti jika harga buah Naga menurun dan kurang Inovasi dalam pengolahan Jamur Tiram. Program ini mendapatkan tanggapan positif dari pemuda Sumberbening karena masalah ekonomi masyarakat yang semakin bertambah dan ini dapat dijadikan industri rumahan yang menadi pemersatu perbedaan dan dapat menambah pendapatan masyarakat sekitarnya.

\section{Referensi}

INAYAH, Nurul et al. Pemberdayaan Masyarakat Dalam Usaha Peningkatan Pendapatan Keluarga Sejahtera (UPKKS). LOYALITAS, Jurnal Pengabdian Kepada Masyarakat, [S.l.], v. 2, n. 1, p. 112-123, may 2019. ISSN 2621-4687. Available at: <http://ejournal.iaida.ac.id/index.php/loyal/article/view/409>. Date accessed: 15 dec. 2020.

JAUHARIYAH, Nur Anim. Kebijakan Pengentasan Kemiskinan Melalui Kajian Potensi Sektor Basis Di Kabupaten Banyuwangi. Jurnal Darussalam: Jurnal Pendidikan, Komunikasi dan Pemikiran Hukum Islam, [S.l.], v. 7, n. 1, p. 112-126, sep. 2015. ISSN 2549-4171. Available at: <http://ejournal.iaida.ac.id/index.php/darussalam/article/view/54>. Date accessed: 15 dec. 2020.

Jauhariyah, Nur Anim dkk. Disparitas Antar Kecamatan Dan Strategi Pembangunan Ekonomi di Kabupaten Banyuwangi. diakses 16 Agustus 2019. http://jurnal.unissula.ac.id/index.php/cbam/article/view/170/0

LPPM, (2019). Buku Pedoman Kuliah Kerja Nyata Participatory action reseach. LPPM-IAIDA Blokagung Banyuwangi.

Kesilir, (2019), Buku Profil Desa Kesilir, Kecamatan Siliragung, Kabupaten Banyuwangi. 